\title{
CZŁONEK CZY SĘDZIA TRYBUNAŁU STANU? UWAGI NA TEMAT STATUSU PRAWNEGO OSÓB ZASIADAJĄCYCH W TRYBUNALE STANU
}

\section{WPROWADZENIE}

Zasadność istnienia Trybunału Stanu (TS) w Polsce bywa kwestionowana nie tylko w publicystyce, ale również $\mathrm{w}$ publikacjach naukowych ${ }^{1}$, a wobec konstrukcji prawnej tego organu można formułować liczne uwagi krytyczne ${ }^{2}$. Nie ulega bowiem wątpliwości, że ten organ władzy sądowniczej jest najmniej „eksploatowanym” organem w Polsce, i to nie tylko biorąc pod uwagę organy konstytucyjne, ale pośród wszystkich organów władzy publicznej.

Tylko teoretycznie może to stanowić potwierdzenie bardzo optymistycznej hipotezy, że w Polsce nie dochodzi do przypadków naruszania Konstytucji lub ustaw w związku z zajmowanym stanowiskiem lub w zakresie swojego urzędowania. Próba obrony takiego wniosku byłaby chybiona z uwagi na zbytnie uproszczenie związane z tym, że hipoteza ta nie uwzględnia innych okoliczności, które faktycznie wpływaja na tak niskie zainteresowanie w uruchamianiu procedury odpowiedzialności konstytucyjnej. Decyzja o uruchomieniu procedury odpowiedzialności konstytucyjnej należy bowiem do większości parlamentarnej, a to powoduje, że ma zdecydowanie polityczny - a nie prawny - charakter. „Parlamentarzyści niechętnie sięgaja po tę formę odpowiedzialności także w stosunku do przeciwników politycznych. Najprawdopodobniej dlatego, iż obawiają się przyszłego jej zastosowania wobec "swojego" premiera"3. Wydaje się, że przyjęta formuła prawna, na której opiera swe istnienie w Polsce TS, jest mocno wadliwa ${ }^{4}$. Poważne wątpliwości związane są również ze statusem osób zasiadających w tym organie władzy sądowniczej.

W przedmiotowym artykule chciałbym się skupić wyłącznie na fragmencie problematyki odnoszacym się do pewnych aspektów sposobu kreacji składu personalnego tego organu, stosowania właściwego nazewnictwa wobec członków TS i niezawisłości orzekających w tym organie członków. Zwrócę uwagę przede wszystkim na niekonsekwencje terminologiczne oraz różnice w statusie członków TS i sędziów innych organów władzy sądowniczej, które pod-

\footnotetext{
1 Ciżyńska (2018): 23.

2 Granat (2006): 140-142.

3 Eckhardt (2018): 535. Także Kowalska (2003): 98-99.

4 Zaleśny (2004a): 285.
} 
ważają zasadność określania członków TS sędziami, co w konsekwencji rodzi wątpliwości o możliwość podejmowania przez członków tego organu czynności orzeczniczych nakreślonych przepisami prawa w sposób niezawisły.

\section{CZŁONEK CZY SĘDZIA TRYBUNAŁU STANU?}

Brak pomysłu na formułę prawną TS jest zauważalny już w warstwie terminologicznej, w szczególności w odniesieniu do osób piastujących funkcje w tym organie: zgodnie z art. 199 ust. 1 Konstytucji RP składa się z przewodniczącego, 2 zastępców przewodniczącego i 16 członków wybieranych przez Sejm spoza grona posłów i senatorów na czas kadencji Sejmu. Zastępcy przewodniczącego Trybunału oraz co najmniej połowa członków TS powinni mieć kwalifikacje wymagane do zajmowania stanowiska sędziego.

Ustrojodawca używa zatem określenia „członek Trybunału Stanu”. Tę, z pozoru konsekwentnie stosowana, konstrukcję terminologiczną zaburza stwierdzenie, że „członkowie Trybunału Stanu w sprawowaniu funkcji sędziego Trybunału Stanu są niezawiśli i podlegają tylko Konstytucji oraz ustawom" (art. 199 ust. 3). Literalnie rzecz ujmując, oznaczałoby to, że członek TS nie jest sędzia, ale pełni (jedynie albo aż) taką funkcję. Tyle że skoro pełni funkcję sędziego, to czy nie powinien być tym sędzią formalnie? W innym wypadku powstaje pytanie o charakter tego stanowiska: czy mamy zatem do czynienia ze swego rodzaju zastępca, substytutem sędziego, asesorem, by nie użyć sformułowania „sędzią drugiej kategorii”? Stosując analogię do procedur w sądach powszechnych, można przyjąć, że status zbliżony do sędziego mają ławnicy i asesorzy. Ci pierwsi sa członkami składu orzekającego, ale nie korzystaja z pełni uprawnień sędziowskich (nie przewodniczą naradzie i posiedzeniom sądu). Asesorzy natomiast przewodniczą rozprawom i wykonują obowiązki sędziowskie samodzielnie, ale wyłącznie w sprawach niższej rangi.

Ten brak konsekwencji terminologicznej jedynie „zasygnalizowany” na gruncie Konstytucji RP ujawnia się w pełni dopiero w ustawie o Trybunale $\mathrm{Stanu}^{5}$. Regulacja ta $\mathrm{w}$ wielu miejscach posługuje się konstytucyjnym określeniem „członek Trybunału Stanu” (np. w art. 15, art. 16 uTS). Ustawodawca używa jednak wobec członków tego organu także sformułowania „sędzia”. W przypadku art. 17 ust. 1 uTS ustawodawca posłużył się tym określeniem pośrednio, stanowiąc o „utracie stanowiska sędziego Trybunału Stanu”. Natomiast bezpośrednio o sędziach Trybunału Stanu mowa jest w art. 19 ust. 2 uTS, który stanowi, że „w drugiej instancji Trybunał Stanu orzeka w składzie: przewodniczący i 6 członków, z wyłączeniem sędziów, którzy uczestniczyli w rozpatrzeniu sprawy w pierwszej instancji”. Wreszcie należy zauważyć, że zgodnie z art. 15 ust. 2 uTS „osoby wybrane w skład Trybunału Stanu składaja przed Marszałkiem Sejmu przyrzeczenie sędziowskie”.

${ }^{5}$ Ustawa z 26 marca 1982 r. o Trybunale Stanu, Dz. U. 2002, Nr 101, poz. 925; 2003, Nr 175, poz. $1692 ; 2004$, Nr 25 , poz. $219 ; 2010$, Nr 75 , poz. $472 ; 182$, poz. $1228 ; 2016$, poz. 437 (dalej jako: uTS). 
Wątpliwości nie rozwiewa nawet sięgnięcie po rozwiązania historyczne, na których to wzorowały się obowiązujące regulacje. Konstytucja marcowa tylko ogólnie wspomina o TS, odwołując się do ustawy szczególnej (art. 51). Natomiast w Konstytucji kwietniowej mowa była expressis verbis o sędziach TS (art. 71 ust. 2). Dla porządku należy przypomnieć, że terminu „członek Trybunału Stanu" konsekwentnie używa się na gruncie Regulaminu Sejmu (art. 26, art. 30 ust. 3 pkt 3, art. 169 ust. 2 pkt 3$)^{6}$.

Brak konsekwencji jest zauważalny także w doktrynie prawa konstytucyjnego. Kazimierz Działocha i Tomasz Zalasiński stosują określenie „sędzia”, pisząc też o „stanowisku sędziego TS” Część autorów posługuje się zamiennie pojęciem członek TS i sędzia TS (np. Bogusław Banaszak ${ }^{8}$, Krzysztof Prokop ${ }^{9}$, Leszek Bosek ${ }^{10}$ ). Ciekawa, acz odosobnioną argumentację odnoszącą się do terminologii prezentuje Artur Ławniczak. Wskazuje on, że sędziowie Trybunału Konstytucyjnego (TK) „nieprzerwanie w trakcie całej kadencji sa otoczeni stuprocentowymi sędziami, podczas gdy ludzie wybrani do Trybunału Stanu sędziami bywaja, co expressis verbis wyrażone zostało w art. 199 ust. 3 [Konstytucji RP]"11.

Stwierdzić zatem należy, że mamy do czynienia z nieładem terminologicznym odnoszącym się do osób piastujących funkcję sędziego w TS. Regulacje prawne charakteryzuje brak konsekwencji w posługiwaniu się stworzona terminologią. W aktach prawnych używa się bowiem zamiennie określenia „członek Trybunału Stanu” i zwrotu „sędzia Trybunału Stanu”, naruszając tym samym podręcznikowe wręcz zasady wykładni językowej, zakazujące terminom brzmiącym odmiennie nadawania tego samego znaczenia ${ }^{12}$.

\section{NIEZAWISŁOŚĆ SECDZIOWSKA A NIEZAWISŁOŚĆ CZŁONKA TRYBUNAŁU STANU}

Stwierdzenie tej niedoskonałości legislacyjnie nakazuje poszukiwanie w dalszym ciagu odpowiedzi na pytanie, kim zatem jest osoba zasiadajacca w TS: członkiem tego organu czy sędzią? Odpowiedź na nie wydaje się szczególnie istotna, gdyż od takiej osoby oczekuje się niezawisłości (art. 199 ust. 3 Konstytucji RP), czyli niezależności w orzekaniu. Warto też zauważyć, że niezależność sądów i niezawisłość sędziów jest uznawana za jedną podstaw pań-

${ }^{6}$ Uchwała Sejmu RP z 30 lipca 1992 r. Regulamin Sejmu Rzeczypospolitej Polskiej, M. P. 2019, poz. 1028, 1184 (dalej jako: RegSej).

7 Działocha, Zalasiński (2007): 2.

8 Banaszak (1999): 544.

9 Prokop (2009): 351.

10 Bosek (2016): Legalis. Autor ten wskazuje, że osoby wchodzące w skład TS nie są sędziami w takim znaczeniu jak sędziowie sądów określonych w art. 175 Konstytucji RP i sędziowie TK”. Chociaż najczęściej posługuje się określeniem „członek TS”, to używa również zamiennie zwrotu „sędzia Trybunału Stanu” lub osoby sprawującej funkcje sędziego TS.

11 Ławniczak (2014): 512-513.

12 Chauvin, Stawecki, Winczorek (2009): 239. 
stwa prawa ${ }^{13}$. Banaszak wskazuje, że „niezawisłość sędziów TS ma charakter analogiczny jak niezawisłość sędziów sądów powszechnych" ${ }^{14}$, ale w kontekście gwarancji niezawisłości sędziowskiej przyznanych obu grupom pogląd ten nie wydaje się trafny.

„Niezawisłość sędziów obejmuje szereg elementów, takich jak: bezstronność w stosunku do uczestników postępowania, niezależność wobec organów (instytucji) pozasądowych, samodzielność sędziego wobec władz i innych organów sądowych, niezależność od wpływu czynników politycznych, zwłaszcza partii politycznych, wewnętrzną niezależność sędziego. Poszanowanie i obrona tych wszystkich elementów niezawisłości jest konstytucyjnym obowiązkiem wszystkich organów i osób stykających się z działalnością sądów, ale także jest konstytucyjnym obowiązkiem samego sędziego. Naruszenie tego obowiąku przez sędziego oznaczać może sprzeniewierzenie się zasadzie niezawisłości sędziowskiej, a to jest równoznaczne z uchybieniem podstawowym zasadom funkcjonowania wymiaru sprawiedliwości"15.

Do gwarancji niezawisłości sędziowskiej zalicza się ponadto stabilizację urzędu sędziego, jego nieusuwalność, immunitet sędziowski, niepołączalność stanowisk i zapewnienie sędziemu odpowiedniego statusu materialnego, który zapewnia im niezależność finansową ${ }^{16}$.

Trybunał Konstytucyjny w wyroku z 9 listopada 1993 r. (K 11/93) wskazał, że: „niezawisłość musi więc oznaczać niezależność sędziego zarówno od stron sporu jak i organów państwa. Korelatem zasady niezawisłości po stronie sędziego jest obowiązek bezstronności, [...] sędzia powinien unikać wszystkiego, co mogłoby osłabiać zaufanie do jego bezstronności”.

Powiązania członków TS z organami państwa są aż nadto oczywiste. Sa oni wybierani na pierwszym posiedzeniu nowo wybranego Sejmu, spoza grona posłów i senatorów, na czas trwania kadencji izby niższej. Zatem skład tego organu określa aktualna większość sejmowa ${ }^{17}$. Tymczasem zgodnie z art. 1 ust. 2 uTS odpowiedzialność przed TS ponoszą również posłowie i senatorowie w zakresie określonym w art. 107 Konstytucji RP. Oznacza to, że posłowie dokonują wyboru swoich potencjalnych sędziów. Taki sposób wyboru osłabia zaufanie do bezstronności członków TS i może podważać niezawisłość tego organu władzy sądowniczej.

W przypadku niektórych osób ponoszących odpowiedzialność konstytucyjną ryzyko podważenia zasady niezawisłości sędziowskiej zostało zniwelowane wskutek zastosowania zasady incompatibilitas. Członkami Trybunału moga zostać tylko obywatele polscy korzystający z pełni praw publicznych, niekarani i niezatrudnieni w organach administracji rządowej ${ }^{18}$. Takie rozwiąza-

13 Zawistowski (2016): 9.

14 Banaszak (2009): 880.

15 Odpowiedź Łukasza Piebiaka na interpelację nr 30374 w sprawie oświadczenia Komisarz Rady Europy ds. Praw Człowieka po wizycie w Polsce z dnia 19.04.2019, <http://www.sejm.gov.pl/ Sejm8.nsf/InterpelacjaTresc.xsp?key=BBJCA2\&view=1> [dostęp: 10.04.2020].

16 Garlicki (1999): 315.

17 Jabłoński, Jarosz-Żukowska (2003): 620.

18 Grabowska (2016): 109. 
nie wyklucza od zasiadania w TS: Prezesa Rady Ministrów, członków Rady Ministrów oraz osób, którym premier powierzył kierowanie ministerstwem. Możliwość łączenia funkcji Prezesa NIK i członka TS wyklucza z kolei art. 205 ust. 2 Konstytucji RP. Natomiast możliwe jest, chociaż dyskusyjne, łączenie stanowiska członka TS z zatrudnieniem w NIK ${ }^{19}$.

Nie ma natomiast formalnego zakazu łączenia przez Prezesa NBP funkcji członka TS. Takiego ograniczenia nie wprowadza bowiem ani art. 227 ust. 4 Konstytucji RP, ani ustawa o $\mathrm{NBP}^{20}$.

Największe wątpliwości budzi natomiast możliwość łączenia funkcji członka Krajowej Rady Radiofonii i Telewizji z członkostwem w TS. Ustawa o KRRiT ${ }^{21}$ stanowi w art. 8 ust. 4, że nie można łączyć funkcji członka Krajowej Rady z posiadaniem udziałów albo akcji spółki bądź w inny sposób uczestniczyć w podmiocie będącym dostawcą usługi medialnej lub producentem radiowym lub telewizyjnym oraz wszelką działalnościa zarobkowa, z wyjątkiem pracy dydaktyczno-naukowej w charakterze nauczyciela akademickiego lub pracy twórczej. Kontrowersje w tym kontekście budzi okoliczność, że członkowie TS swoją funkcje pełnią honorowo, czyli nieodpłatnie. Otrzymywana dieta ma jedynie rekompensować ponoszone przez członka TS wydatki w związku z wykonywaniem czynności w Trybunale, gdyż kwota w wysokości 10\% przeciętnego wynagrodzenia za każdy dzień udziału w pracach Trybunału nie jest szczególnie wygórowana ${ }^{22}$. Ponadto członkowie TS otrzymuja zwrot poniesionych kosztów podróży i zakwaterowania (na zasadach określonych w przepisach dotyczących ustalania należności przysługujących pracownikom z tytułu podróży służbowej na obszarze kraju, wydanych na podstawie Kodeksu pracy). Nie do końca ustalony jest charakter takiej diety: czy jest to szczególna postać diety za czas podróży służbowej, która ma pokrywać zwiększone koszty wyżywienia w czasie podróży, czy jakaś inna forma gratyfikacji dla korzystającego z tego świadczenia? Oznaczać to może, że łączenie tych stanowisk jest potencjalnie możliwe przy przyjęciu założenia, że dieta nie jest wynagrodzeniem ${ }^{23}$. Tytułem uwag de lege ferenda zasadne byłoby postulowanie, aby konstrukcja niepołączalności członka TS odnosiła się do zatrudnienia we wszystkich instytucjach, których prezesi lub członkowie moga ponosić odpowiedzialność konstytucyjna

Okoliczność, że członkowie TK nie pobierają za sprawowaną funkcję wynagrodzenia, powoduje, że ich status prawny jest pozbawiony kolejnej cechy niezawisłości sędziowskiej, a mianowicie prawa do wynagrodzenia odpowiadającego godności urzędu oraz zakresowi obowiązków. Takie ujęcie nie jest sprzeczne z Konstytucja, która wymóg uzyskiwania godnego wynagrodzenia

19 Działocha, Zalasiński (2007): 3.

${ }^{20}$ Ustawa z 29 sierpnia 1997 r. o Narodowym Banku Polskim, Dz. U. 2019, poz. 1810; 2020, poz. 568).

21 Ustawa z 29 grudnia 1992 r. o radiofonii i telewizji, Dz. U. 1993, Nr 7, 34 ze zm.

22 Przeciętne wynagrodzenie w gospodarce narodowej w 2019 r. wyniosło 4918,17 zł - komunikat Prezesa Głównego Urzędu Statystycznego z 11 lutego 2020 r. w sprawie przeciętnego wynagrodzenia w gospodarce narodowej w 2019 r. (M. P. poz. 174).

${ }^{23}$ Zaleśny (2004b): 144. 
wprowadza expressis verbis wobec sędziów sądów powoływanych przez Prezydenta i sędziów TK ${ }^{24}$. Trybunał Konstytucyjny uznał bowiem, że „godność urzędu to świadomość jego wartości i szacunek dlań, żywiony zarówno przez osoby go pełniące, jak i przez osoby postronne, a szerzej - całe społeczeństwo; w pojęciu tym zawiera się także poczucie dumy z przynależności do grupy osób urząd ten sprawujących" 25 ; podtrzymał wyrażony w uzasadnieniu postanowienia z 22 marca 2000 r. pogląd, iż: „godność urzędu musi być realizowana wielopłaszczyznowo, w pierwszym rzędzie przez takie sprawowanie wymiaru sprawiedliwości, aby utrwalało ono obraz sądu bezstronnego, sprawiedliwego i niezawisłego". Odnosząc się natomiast do minimalnych wymogów dla ustawowych regulacji wynagrodzeń sędziowskich, TK wskazał, że wynagrodzenia te powinny „być ustalane przez odniesienie do przeciętnego wynagrodzenia w sferze budżetowej i znacząco przekraczać poziom tego wynagrodzenia" 26 .

Trudno jest zatem mówić o zapewnieniu tej gwarancji niezawisłości sędziowskiej w odniesieniu do członków Trybunału Stanu. Można oczywiście z tym twierdzeniem polemizować, podnosząc, że dieta jest ustalana na podstawie przeciętnego wynagrodzenia w sferze budżetowej oraz że jej wysokość jest znacząco wyższa w przeliczeniu na dzień pracy. Wymagałoby tojednak, po pierwsze, uznania diety za wynagrodzenie, co - w moim przekonaniu jest mocno dyskusyjne. Po drugie, brak uzyskiwania jakieś formy gratyfikacji finansowej za byciem członkiem TS może podważać zaufanie do osoby sprawującej tę funkcję jako osoby bezstronnej i niezawisłej. Utrzymywanie godnego wynagrodzenia wzmacnia bowiem poczucie niezależności i ogranicza - przynajmniej w teorii - skłonność do nadużyć i korupcji. Okoliczność ta podważa możliwość określania członków TS „sędziami”. Tym bardziej że członkowie Państwowej Komisji Wyborczej, którzy aktywizuja się jedynie kilkukrotnie w trakcie pełnienia swojej funkcji w okresie kadencji, głównie w okresie wyborczym, otrzymują wynagrodzenie miesięczne ustalane na podstawie kwoty bazowej przyjmowanej do ustalenia wynagrodzenia osób zajmujących kierownicze stanowiska państwowe, z zastosowaniem mnożników: 1) dla przewodniczącego - 3,5; 2) dla zastępcy przewodniczącego - 3,2; 3) dla członków Komisji - 3,0 (art. 159 § 2 Kodeksu wyborczego).

Tytułem uwag de lege ferenda warto byłoby zastanowić się nad podniesieniem statusu członków TS i - wzorem Kodeksu wyborczego - ustalić dla członków tego konstytucyjnego organu stałe, miesięczne wynagrodzenie w odpowiedniej, godnej do sprawowanej funkcji, wysokości. Wypłacanie diety wyłącznie za czas orzekania nie spełnia bowiem wymogu zapewnienia funkcjonalnej gwarancji sędziowskiej w postaci materialnej niezależności sędziów. Dzięki pobieraniu wynagrodzenia członkowie TS staliby się również bardziej niezależni materialnie od dotychczasowego pracodawcy, co wzmocniłoby ich niezależność i niezawisłość.

\footnotetext{
${ }^{24}$ Więcej na temat wynagrodzenia w Konstytucji zob. Musiałowicz (2014).

25 Wyrok TK z 12.12.2012 r., K 1/12.

26 Duszka-Jakimko, Jakimko (2013): 124-130.
} 
Wreszcie należy zauważyć, że członkowie TS sa, podobnie jak sędziowie, nieusuwalni, tę gwarancję niezawisłości sędziowskiej osłabia jednak znacząco krótki, gdyż 4-letni okres sprawowania przez nich kadencji, a ponadto jej powiązanie z kadencją Sejmu. W przypadku skróceniu kadencji Sejmu, co może nastapić z przyczyn politycznych, dochodzi bowiem także do skrócenia kadencji TS.

Nie budzi wątpliwości, że niezawisłość członków TS w porównaniu z niezawisłością sędziowską doznaje poważnych ograniczeńn ${ }^{27}$. Może to mieć istotny wpływ na swobodę orzekania i niezależność tego organu od innych władz. Tym bardziej że dopuszczalne jest wykonywanie funkcji członka TS. Stanowić to może pokusę do bycia „dyspozycyjnym” członkiem TS.

\section{APOLITYCZNOŚĆ CZŁONKA TRYBUNAŁU STANU}

Jedną z niepodważalnych gwarancji niezawisłości sędziowskiej jest apolityczność sędziego. W ujęciu słownikowym jest ona rozumiana jako „niebranie udziału w życiu politycznym, nieinteresowanie się polityką". Definicja ta nie przystaje jednak do języka prawnego, na gruncie którego termin ten należy rozumieć $\mathrm{w}$ sensie formalnym jako brak przynależności do partii politycznej ${ }^{28}$. Lech Gardocki wskazuje, że „specyfika funkcji sędziowskiej, potrzeba zachowania przez sędziów niezawisłości i obiektywizmu uzasadnia nałożenie na nich takiego obowiązku. Być może wielu sędziów takiego ograniczenia nie potrzebuje, ale ważne jest także, aby nie stwarzać nawet pozorów braku obiektywizmu z powodów politycznych" 29 .

W przypadku sędziów sądów powszechnych obowiązek ich apolityczności wprowadza Konstytucja RP w art. 178. Tymczasem podobnego wymogu nie wprowadzono wprost wobec członków TS, i to nie tylko w ustawie zasadniczej, lecz także w ustawie o TS. Z pomocą nie przychodzi również tekst przyrzeczenia sędziowskiego, w którym nie ma mowy o obowiązku zachowania apolityczności.

Problematyczne wydaje się uznanie, że konieczność dochowania wymogu apolityczności mieści się w konstytucyjnej formule stanowiącej, że zastępcy oraz „co najmniej połowa członków Trybunału Stanu powinni mieć kwalifikacje wymagane do zajmowania stanowiska sędziowskiego" (art. 199 ust. 1 Konstytucji RP). Wśród kwalifikacji na stanowisko sędziego sądu rejonowego w art. $61 \S 1$ Prawa o ustroju sądów powszechnych ${ }^{30}$ nie wymienia się bowiem wymogu apolityczności. Oznacza to, że członkowie TS nie zostali formalnie, na gruncie obowiązującego prawa, zobowiązani do spełniania obowiązu apolityczności.

${ }^{27}$ Bosek (2016) wskazuje, że „funkcjonalne ograniczenie niezawisłości sędziowskiej członków TS stawia jednak pytanie o realność tej niezawisłości”.

$28<$ https://sjp.pwn.pl/slowniki/apolityczny.html> [dostęp: 20.05.2020].

29 Gardocki (1998).

30 Ustawa z 27 lipca 2001 r., Dz. U. 2020, poz. 365, 288. 
Zbadać należy, czy wprowadzenie wymogu przestrzegania apolityczności wobec członków TS jest konieczne, skoro wymaga się od nich niezawisłości. Teoretycznie można bowiem przyjąć, że pojęcie niezawisłości zawiera już w sobie konieczność spełnienia wymogu apolityczności. Te hipotetyczne założenie podważa jednak okoliczność, że ustawodawca nakłada na sędziów, w odrębnej jednostce redakcyjnej tekstu prawnego, zakaz przynależności do partii politycznej i związków zawodowych (art. 178 ust. 3 Konstytucji RP). Oznacza to, że apolityczność jest odrębnym od niezawisłości wymogiem.

Oznaczać to może, że wobec członków TS nie wprowadzono obowiązku zachowania apolityczności ani z chwila wyboru w poczet członków tego organu, ani na etapie późniejszym, z chwilą wylosowania do składu orzekającego w konkretnej sprawie. Uzasadnione wydaje się w związku z tym dokonanie nowelizacji ustawy o TS w taki sposób, aby członkowie tego organu atrybutem apolityczności mogli się okazać. Możliwe są przy tym dwa rozwiązania. Pierwsze, które w sposób bezwzględny wyłącza jakiekolwiek powiązania polityczne i wprowadza wymóg braku przynależności partyjnej w momencie obejmowania funkcji. I drugie, które nakazuje jedynie zawieszenie członkostwa w partii politycznej na okres kadencji w TS. Bez względu na redakcję tych nakazów powinny one objaćc również zakaz przynależności lub przynajmniej zawieszenie członkostwa w związkach zawodowych. Należy jednak wskazać, że zawieszenie członkostwa nie przecina zupełnie związków z danym ugrupowaniem i w dalszym ciagu może stanowić zagrożenie dla zasady apolityczności.

\section{ZAKOŃCZENIE}

Analiza statusu prawnego członków Trybunału Stanu ukazuje, że wobec osób zajmujących tę funkcję nie wprowadzono kilku istotnych gwarancji niezawisłości sędziowskiej. Brak jest bowiem zagwarantowania piastunom odpowiedniego statusu materialnego, nie wprowadzono wymogu zachowania apolityczności, a ponadto poważne wątpliwości budzi konstrukcja mechanizmu incompatibilitas, który wobec nich zastosowano. Charakter pełnionej przez nich funkcji dodatkowo utrudnia brak stosowania jednolitej terminologii przez prawodawców.

Biorąc powyższe pod uwagę, należy stwierdzić, że osoby zasiadające w TS z wyjątkiem przewodniczącego tego organu - nie są sędziami i należy ich określać jako członków TS. Brak zapewnienia członkom Trybunału wszystkich gwarancji niezawisłości sędziowskiej nie dyskwalifikuje ich jako osób, które sa członkami szeroko rozumianego aparatu sądowego i które rozstrzygają spory o prawo przez orzekanie w organie władzy sądowniczej. Nie stają się jednak sędziami nawet wtedy, gdy orzekaja w sprawach o przestępstwo i sprawuja wymiar sprawiedliwości.

Zmiana w postrzeganiu charakterystyki urzędu członka TS wymagałaby wprowadzenia zmian odnoszacych się do jego statusu i przyznanie mu odpowiednich gwarancji niezawisłości sędziowskiej. Do uznania członków TS za 
sędziów konieczne byłoby także objęcie wszystkich członków tego organu wymogiem posiadania kwalifikacji do zajmowania stanowiska sędziego. Brak nowelizacji Konstytucji w tym zakresie, przy wprowadzeniu postulowanych zmian odnoszących się do gwarancji niezawisłości sędziowskiej, mógłby doprowadzić do hipotetycznej sytuacji, w której część osób mających kwalifikacje do zajmowania stanowiska byłaby sędziami, w przeciwieństwie do pozostałych „członków” tego organu (takie zjawisko jest jednak znane polskiemu wymiarowi sprawiedliwości i obecności ławników w niektórych składach orzekających sądów powszechnych ${ }^{31}$ ). W tym względzie warto byłoby powrócić do znanej z Konstytucji kwietniowej formuły powoływania sędziów TS spośród sędziów sądów powszechnych ${ }^{32}$.

Waskie ramy niniejszego artykułu nie pozwalaja na wskazanie przyczyn, z powodu których mechanizm odpowiedzialności konstytucyjnej jest w naszym państwie tak sporadycznie uruchamiany. Wydaje się jednak, że jednym z powodów tego stanu rzeczy, ale nie kluczowym, jest brak zapewnienia członkom tego organu wszystkich gwarancji służących niezawisłemu sprawowania funkcji orzeczniczych.

Pawet Kuczma

Uniwersytet Zielonogórski

p.kuczma@wpa.uz.zgora.pl

https://orcid.org/0000-0003-1443-4742

Banaszak, B. (1999). Prawo konstytucyjne. Warszawa.

Bosek, L. (2016). Art. 199, [w:] M. Safjan, L. Bosek (red.). Konstytucja RP. Tom 2. Warszawa. Legalis.

Chauvin, T., Stawecki, T., Winczorek, P. (2009). Wstęp do prawoznawstwa. Warszawa.

Ciżyńska, A. (2018). Zasadność istnienia Trybunału Stanu w systemie organów państwa Rzeczypospolitej Polskiej. Przegląd Prawno-Ekonomiczny 2(43): 9-28.

Działocha, K., Zalasiński, T. (2007). Art. 199, [w:] L. Garlicki (red.), Konstytucja Rzeczypospolitej Polskiej. Komentarz. Warszawa: 3.

Duszka-Jakimko, H., Jakimko, W. (2013). Budżetowa godność wynagrodzenia sędziego. Iustitia 3(13): 124-130.

Eckhardt, K. (2018). Odpowiedzialność konstytucyjna prezesa Rady Ministrów. Gdańskie Studia Prawnicze 40: 525-536.

Gardocki, L. (1998). Apolityczność sędziów. Rzeczpospolita 7 grudnia 1998.

Garlicki, L. (1999). Polskie prawo Konstytucyjne. Zarys wykładu. Warszawa.

Grabowska, S. (2016). Trybunał Stanu jako specjalny organ orzekający w sprawie odpowiedzialności konstytucyjnej prezydenta. Studia Politologiczne 42: 107-123.

Granat, M. (2006), Normatywny model odpowiedzialności konstytucyjnej w praktyce, [w:] W. Skrzydło (red.), Sądy i trybunały w konstytucji i praktyce. Warszawa: 140-142.

Jabłoński, M., Jarosz-Żukowska, S. (2003). Prawo konstytucyjne w formie pytań i odpowiedzi. Wrocław.

${ }^{31}$ Ziółkowska (2014): 69-78.

${ }^{32}$ W Konstytucji kwietniowej to Prezydent powoływał sędziów TS „spośród sędziów sąów powszechnych, przedstawionych w liczbie podwójnej w połowie przez Sejm, a w połowie przez Senat, z równomiernym uwzględnieniem kandydatów każdej z Izb Ustawodawczych" (art. 71 ust. 2). Analiza sposobu wyboru wymaga odrębnej analizy, postulat de lege ferenda dotyczy wyłącznie tego, kto może zostać członkiem TS. 
Kowalska, M. (2003). Polityczny wymiar odpowiedzialności konstytucyjnej członków Rady Ministrów. Annales Universitatis Mariae Curie-Skłodowska. Sectio K, Politologia 10: 93-107.

Musiałowicz, E. (2014). Zagadnienie pracy i wynagrodzenia za pracę w Konstytucji RP z 2 kwietnia 1997 r. Przegląd Prawniczy, Ekonomiczny i Społeczny 4: 78-88.

Ławniczak, A. (2014). Art. 200, [w:] M. Haczkowska (red.), Komentarz. Konstytucja Rzeczypospolitej Polskiej Warszawa: 512-513.

Prokop, K. (2009). Trybunał Stanu, [w:] M. Grzybowski (red.), Prawo konstytucyjne. Białystok: $348-376$.

Zawistowski, D. (2016). Niezależność sądów i niezawisłość sędziów z perspektywy prawa Unii Europejskiej. Ruch Prawniczy, Ekonomiczny i Socjologiczny 78(2): 7-13.

Zaleśny, J. (2004): Odpowiedzialność konstytucyjna. Praktyka III RP. Warszawa.

Zaleśny, J. (2004b): Odpowiedzialność konstytucyjna w prawie polskim okresu transformacji ustrojowej. Toruń.

Ziółkowska, K. (2014). Rola ławnika sądowego w polskim systemie wymiaru sprawiedliwości. Media - Kultura - Komunikacja Społeczna 10(4): 69-78.

\section{A MEMBER OR JUDGE OF THE STATE TRIBUNAL? COMMENTS ON THE LEGAL STATUS OF PERSONS SITTING ON THE STATE TRIBUNAL}

\section{$\mathrm{Sum}$ m a r y}

The article analyses the legal status of persons sitting on the State Tribunal in order to determine the legal nature of the function of a member of the State Tribunal. The State Tribunal in Poland is basically a dead institution and it is reasonable to examine the reasons for this phenomenon. In connection with this, research was conducted on how to create the personal composition of this body, and on the independence of its members and their apoliticality. It turns out that the legal formula on which the State Tribunal bases its existence in Poland is seriously flawed. Members of the State Tribunal were not assured all guarantees of judicial independence. Consequently, those sitting on the State Tribunal - with the exception of the chairman of this body - are not judges and should be identified as members of the State Tribunal. The work also formulates de lege ferenda comments.

Keywords: State Tribunal; constitutional liability; guarantees of judicial independence; apoliticality; imcompatibilitas; impeachment 